\title{
Consequences of Swidden Transitions for Crop and Fallow Biodiversity in Southeast Asia
}

\author{
Kanok Rerkasem • Deborah Lawrence • \\ Christine Padoch • Dietrich Schmidt-Vogt • \\ Alan D. Ziegler • Thilde Bech Bruun
}

Published online: 5 June 2009

(C) Springer Science + Business Media, LLC 2009

\begin{abstract}
Swidden agriculture, once the dominant form of land use throughout the uplands and much of the lowlands of Southeast Asia, is being replaced by other land uses. While change and adaptation are inherent to swiddening, the current rapid and widespread transitions are unprecedented. In this paper we review some recent findings on changes in biodiversity, especially plant diversity at various scales, as swidden farming is replaced by other land uses. We focus particularly on two areas of Southeast Asia:
\end{abstract}

\footnotetext{
K. Rerkasem

Plant Genetic Resource and Nutrition Lab, Faculty of Agriculture, Chiang Mai University,

Chiang Mai, Thailand

e-mail: kanok@chiangmai.ac.th

D. Lawrence

Department of Environmental Sciences, University of Virginia,

Charlottesville, VA, USA

e-mail: Lawrence@virginia.edu

C. Padoch $(\bowtie)$

Institute of Economic Botany, New York Botanical Garden,

Bronx, NY, USA

e-mail: cpadoch@nybg.org

D. Schmidt-Vogt

School of Environment, Resources and Development,

Asian Institute of Technology,

Pathum Thani, Thailand

e-mail:schmidt@ait.ac.th

\author{
A. D. Ziegler \\ Geography Department, National University of Singapore, \\ Singapore, Singapore \\ e-mail: adz@nus.edu.sg \\ T. B. Bruun \\ Department of Geography and Geology, University of Copenhagen, \\ Copenhagen, Denmark
}

e-mail: tbb@geogr.ku.dk
}

northern Thailand and West Kalimantan. We examine actual and potential changes in the diversity of crops that characterize regional swidden systems, as well as that of the spontaneously occurring plants that appear in swidden fields and fallows. Severe declines in plant diversity have been observed in most areas and at most spatial scales when swidden is replaced by permanent land use systems. However, shifts away from swidden agriculture do not invariably result in drastic declines or losses of biological diversity, but may maintain or even enhance it, particularly at finer spatial scales. We suggest that further research is necessary to understand the effects of swidden transitions on biodiversity.

Keywords Swidden agriculture · Agrobiodiversity Crop diversity $\cdot$ Swidden fallows $\cdot$ Agrodiversity

\section{Introduction}

Traditional swidden ecosystems in Southeast Asia are known historically to be rich in agricultural crops and semi-domesticated plants as well as in the spontaneous vegetation that appears in both the cropping and fallowing phases (Conklin 1957; Spencer 1966; Warner 1991; Rerkasem 1996). Swiddening is also referred to as shifting cultivation or slash-and-burn agriculture. (For a definition of swidden cultivation, please see the introduction to this issue (Mertz et al. 2009, this issue). From the uplands of montane mainland Southeast Asia to the islands of Indonesia and the Philippines, swidden systems are now being replaced by a variety of permanent agricultural and non-agricultural land uses (Guo et al. 2002). Driving this change, in part, has been the official view of governments throughout the region that swiddening is an unacceptable, 
destructive practice (Cramb et al. 2009; Fox et al. 2000; this issue). Myriad policies and measures have been applied over the last several decades to curb swidden cultivation (cf. Fox et al. this issue; Schmidt-Vogt 2001; Delang 2002; Fox and Vogler 2005; Thongmanivong et al. 2005). Demographic, technological, and economic shifts have also helped change the crops that are planted and the ways fallows are managed, both spatially and temporally (Guo et al. 2002; Rasul and Thapa 2003; Padoch et al. 2007; Cairns 2007b). These rapid transformations have important implications for biodiversity in the Southeast Asia region.

In this article, we review what is known about plant biodiversity in Southeast Asian swidden fields and fallows, focusing attention on two areas: northern Thailand (and neighboring areas of montane mainland Southeast Asia) and West Kalimantan in Indonesia (and neighboring areas of Sarawak in Malaysia). We then explore how recent shifts in land use away from swiddening are affecting plant diversity on several levels: e.g., losses of local germplasm and of swidden crops, degradation of swidden fallows, as well as losses of entire agroecosystems. Finally, we examine several instances where swidden crop and other biodiversity is being maintained and even created, despite pervasive and profound land-use change.

\section{Biodiversity in Swidden Ecosystems}

\section{The Cropping Phase}

Perhaps the best-known study of swidden in Southeast Asia is the pioneering work on the swiddens of the Hanunoo of Mindoro Island in the Philippines by Conklin (1957). The large number of crops and landraces encountered in Hanunoo swiddens - over 280 types of food crops and 92 recognized rice varieties, with several dozen usually showing up in any particular swidden field-has often been cited as a hallmark of intact swidden diversity in the region. Another well-known early compendium of data on swiddening in Southeast Asia (that encompassed an expanded area including Papua New Guinea and parts of India) listed over 250 species as "crop plants cultivated by shifting cultivators" (Spencer 1966: App. D). More recently, researchers have commonly identified some 30 species of staple crops, 30-40 species of vegetables, and 25 species of herbs and spices in upland rice swidden fields of Southeast Asia during the cropping phase (Anderson 1993; Sutthi 1995; Dove 1985; Colfer et al. 1997). Swiddens largely devoted to opium poppy cultivation in the "Golden Triangle" of the mountainous mainland often included somewhat lesser crop diversity (commonly including 15-20 species of vegetables and a few herbs
(Crooker 1986; Hansen 1995; Sutthi 1995; Rerkasem et al. 1989). These studies suggest there is a great wealth of agricultural biodiversity maintained in swidden systems. However, assessing what is actually being lost as swiddening is replaced by other land uses is not straightforward.

Despite apparent region-wide regularities, when viewed on a smaller scale, swiddens vary greatly from locale to locale, field to field, and year to year. In general, the number and variety of crops grown in swiddens by individual households depend on the physical character of the fields (slope, aspect, soil fertility, and other field features including ash cover, density of termite mounds or burned stumps), availability of seeds and planting material, involvement of households in additional economic activities including various forms of cash cropping, and myriad other household decisions. In Karen swiddens in Sop Moei district of Mae Hong Son province in northern Thailand, a 4-year study found that about 50-60 species of crops, including a few ornamentals, were characteristically found in local swidden fields (Yimyam 2006). However, the number of crops grown in association with upland rice by any individual household varied from 18 to almost 50 species, and that number often changed from year to year. Both the distribution and abundance of crop species were determined by multiple factors, among them the soil type, the maturation time of the particular crop, its growth habit, and harvest season. Leaf mustard (Brassica juncea), for example, was grown densely since it was ready to be harvested about one month after upland rice was sown and thus interfered minimally with the production and harvesting of rice, the most important crop. In contrast, the abundance of black cowpeas (Vigna unticulata) was kept as low as 18-30 plants/ha because of the potential of this creeping, climbing species to smother rice plants. Finally, some crops were planted in particular patterns and served several purposes at once. Cassava (Manihot esculenta) was frequently grown in single rows within the large, multifamily swiddens, not only for food and/or animal feed, but also to indicate a plot boundary.

The agricultural biodiversity of Southeast Asia's swiddens is not only varied and complex, it has also been changing since long before the present rapid land-use transitions began. Intercropped species such as yams (Dioscorea spp.) and taro (Colocasia esculenta) may have once been the dominant staples in swiddens throughout much of the Asian tropics (Spencer 1966). However these native tuber crops have largely been relegated to secondary status in Southeast Asian swiddens by grain crops notably rice, but also others such as millet (Setaria italica) and Job's tears (Coix lachryma-jobi). In recent years, however, many of these local secondary crops have in turn been replaced by an array of species brought in from the Americas and elsewhere, including cassava, maize, chilies, 
and peanuts (Arachis hypogaea) (Spencer 1966; Cramb 2007). Diversity and change have long characterized swidden crops in Southeast Asia: new species have been adopted, old ones abandoned, and yet others moved into and out of swiddens to other environments. For an area as large, diverse, and dynamic as Southeast Asia, we cannot offer an assessment of how many crop species, if any, are being lost as the current swidden transition continues, but change - and loss - at the varietal level is apparently occurring much more rapidly than before.

\section{Genetic Diversity of Domesticated Species}

In addition to the inclusion of a great many different crop species in Southeast Asian swiddens, management and utilization of multiple varieties of most crops is common among the myriad ethnic groups of both the mainland and islands of Southeast Asia. Levels of intra-specific diversity of upland crops vary considerably, with most farmers maintaining more than one variety (landrace) of crops for cultivation. These patterns reflect to a large extent other patterns of diversity in swidden systems, i.e., biophysical diversity, management or technological diversity, cultural and organizational diversity (Brookfield et al. 2003). Changing relationships among social groups, patterns of exchange of planting materials, as well as, recent migration and political change have all been shown to affect crop genetic resources (Coffey 2008; Jarvis et al. 2007). Evidence indicates that women of swiddening households frequently play key roles in the maintenance and management of the crops as well as in the collection of important germplasm and that their changing roles affect the state of crop genetic resources (Colfer 2008).

The centre of diversity for cultivated rice (Oryza sativa) coincides roughly with montane mainland Southeast Asia (MMSEA), which includes the mountainous areas of Cambodia, Myanmar, Thailand, Laos, Vietnam and Southwest China (Chang 1976; Morishima et al. 1980). Swidden practices in this region likely have played significant roles in creating, maintaining, and conserving genetic resources of rice for many centuries. As has been observed in many other areas (Maxted et al. 1997; Nazarea 2006), agricultural development in the past 50 years has resulted in the erosion of crop genetic diversity. In the case of MMSEA, numerous rice landraces have been replaced with relatively few improved or modern high-yielding varieties (HYVs) in the major rice growing areas. In China's Yunnan Province and in Vietnam, where statistics show that $81 \%$ and $90 \%$, respectively, of rice areas are planted to high yielding varieties and hybrids, local upland races still can be found among farmers who continue to depend on upland cultivation for their livelihoods (FAO 2009; IRRI 2008). It is notable that in 1985, the anthropologist Yin Shaoting had recorded 71 named varieties of rice cultivated by Jinuo communities in Yunnan, and noted that about 30 traditional varieties had already been lost (Yin 2001). In Yunnan, Jinuo are only one of about 25 officially recognized ethnic groups-many of them once swiddeners. In Laos, the government has been successful in replacing most of the local rice germplasm with improved varieties in the Mekong provinces within the last 2-3 years. The northern provinces were, however, still almost exclusively dependent on local varieties in 2002 (Mounmeuangxam 2003). Khamu swiddeners in northwestern Laos, for example, were found to cultivate ten different varieties of rice in one large swidden arranged along an altitudinal gradient of $150 \mathrm{~m}$ (Evrard 2006). While adoption of HYVs has been less extensive than in many other Southeast Asian countries, Thailand has seen improved varieties spread throughout most of its lowland valleys. The richest diversity in local rice germplasm is found in the unique highland ecosystems that were once dominated by traditional swiddening (Rerkasem 2008).

Throughout the region, much rice diversity, from the level of the seedlot to named varieties, has been maintained through local seed exchange networks that operate within and between communities, and at different scales from the village to district and provincial levels. In Samneua district of Houaphanh province in Laos, a total of 19 varieties were found in three villages (Mounmeuangxam 2003). Much variation, however, was found to exist among seedlots of what was recognized as the same, named variety. High levels of intra-varietal diversity are typical of rice landraces as well as other swidden crops; this level of diversity often goes unrecognized and unappreciated when comparisons are made of crop diversity in "traditional" (including swidden) systems and in modern cropping.

Another study set in Tee Cha, a Pwo Karen village in Sop Moei district of Thailand's Mae Hong Son province, documented the functioning of complex seed exchange networks. At first glance, there appeared to be a rich diversity of rice varieties in the village. Each farm household grew between two and five of the more than 20 documented varieties, depending on the availability of rice lands, biophysical properties of the fields, as well as personal choices (Table 1). However, only a handful of varieties were grown by the majority of farmers; others were rare. Because of biophysical constraints and management considerations, farmers tended to renew their seeds over short periods of time and seed exchange patterns were complicated (Table 1). Inside the village of Tee Chaespecially within families - exchanges were limited by particular kinship-based rules. High levels of genetic diversity were maintained, in part, because seeds were also exchanged outside the village through alternative kinshipbased networks or with other communities where traditional 
Table 1 Seed turnover of local rice varieties in Tee Cha village, 2001-2005

\begin{tabular}{|c|c|c|c|c|}
\hline $\begin{array}{l}\text { Variety } \\
\text { name }^{\mathrm{a}}\end{array}$ & $\begin{array}{l}\text { Number } \\
\text { of farmers } \\
\text { growing } \\
\text { the variety }\end{array}$ & $\begin{array}{l}\text { Growers as } \\
\text { Percent of } \\
\text { Village } \\
(N=37)\end{array}$ & Acquired $^{\mathrm{c}}$ & Abandoned $^{\mathrm{d}}$ \\
\hline Bue Bang & 16 & 43 & 6 & 9 \\
\hline Bue Gau & 15 & 41 & 8 & 9 \\
\hline Bue Mue Ta Bong & 14 & 38 & 3 & 2 \\
\hline Bue Chu & 10 & 27 & 8 & 4 \\
\hline Bue Goal & 8 & 22 & 4 & 4 \\
\hline Bue Paw Law & 8 & 22 & 5 & 2 \\
\hline Bue Kee & 3 & 8 & 2 & 0 \\
\hline Bue Tho Lae & 3 & 8 & 0 & 2 \\
\hline Bue Tor $\mathrm{Na}$ & 3 & 8 & 3 & 2 \\
\hline Bue Pho Rai & 2 & 5 & 1 & 0 \\
\hline Bue Khu Koo & 1 & 3 & 0 & 0 \\
\hline Bue Sor May & 1 & 3 & 2 & 1 \\
\hline Pa Ai Khu Phae & 24 & 65 & 8 & 10 \\
\hline Pa Ai Goal & 9 & 24 & 8 & 3 \\
\hline Pa Ai Chai & 3 & 8 & 2 & 2 \\
\hline Pa Ai Ki Kai & 3 & 8 & 2 & 3 \\
\hline Pa Ai Bang & 2 & 5 & 2 & 0 \\
\hline Pa Ai Chair & 2 & 5 & 1 & 0 \\
\hline Bue Ka Set ${ }^{\mathrm{e}}$ & 4 & 11 & 1 & 2 \\
\hline Bue Huai Singh $^{\mathrm{e}}$ & 1 & 3 & 1 & 0 \\
\hline $\mathrm{Pa} \mathrm{Ai} \mathrm{Na} \mathrm{e}^{\mathrm{e}}$ & 1 & 3 & 0 & 0 \\
\hline
\end{tabular}

$\overline{\text { a In the Karen language 'Bue' designates non-glutinous varieties and }}$ 'Pa Ai' designates glutinous varieties.

${ }^{\mathrm{b}}$ The total number of farmers who grew the specified variety at least once during the 5 years study

${ }^{\mathrm{c}}$ Number of farmers who started to grow the variety after not growing it for more than 1 year during the 5 years study

${ }^{\mathrm{d}}$ Number of farmers who grew the variety and then stopped for at least 1 year during the 5 years study

${ }^{\mathrm{e}}$ Paddy rice

rules and regulations of rice seed exchange did not apply, e.g., with Christian communities and with other ethnic communities such as Lua, Shan, and lowland Thai (Sirabanchongkran et al. 2004). The existing genetic diversity in rice in the region is clearly the product of the interaction of a great many processes, economic, social, political, agricultural and environmental. Swiddening is at the center of many of these interactions.

Studies carried out in swiddening communities in Indonesia and Malaysia have also often indicated high numbers of rice varieties. In 1975, farmers in just one small Kantu' Dayak village in West Kalimantan, for example, planted 44 distinct, named varieties of rice (Dove 1985). Even higher levels were found in Sarawak in the 1990s, where 105 named varieties were observed in an inland Iban community, while 79 named rice varieties were observed in an Iban village closer to the coast (Mertz and Christensen 1997). High intra-specific diversity in rice was also found in Kenyah Dayak communities in East Kalimantan in the 1980s (Colfer et al. 1997, Colfer and Dudley 1993). Research in Tara'n Dayaks villages in West Kalimantan, in the 1990s however, showed only five or six varieties as the village norm (Padoch unpublished data). In the Moyog constituency on the western flank of the Crocker Range in Sabah, the variety of hill rice grown differed according local climatic conditions and family socio-economic circumstances (Lim and Douglas 1998). For example, farmers who still depended on rice to feed their families often planted more than one variety. In two cool and high-elevation villages $(>1,000 \mathrm{~m})$ located about $5 \mathrm{~km}$ apart, six mutually exclusive varieties were planted. In warmer villages located at elevations $<300 \mathrm{~m}$, three or fewer varieties where planted. In villages where cash cropping was prominent, only one variety was planted. While discrepancy in the total number of varieties may reflect the variation from place to place and group to group as noted above, it may provide some indication of a general reduction in agrodiversity over the last few decades, as is the case with the cash cropping villages in the last example.

\section{The Fallow Phase}

Swidden fallows play a crucial role in maintaining the sustainability of swidden systems in various ways: by restoring fertility of the soil-vegetation system and facilitating weed control (Nye and Greenland 1960), by providing a wealth of plant and wildlife products for subsistence and sale (Anderson 1993), and by providing ecosystem services such as regulating water flow, protection against erosion (Ziegler et al. 2009b), maintaining long-term carbon stocks (Bruun et al. 2009), and habitat for wild plants and animals on a larger landscape scale. Depending on management practices, especially the length of the fallow period, fallow vegetation develops through a sequence of successional stages, the early stages being characteristically dominated by herbaceous plants, the later stages being increasingly dominated by woody growth ranging from secondary scrub to secondary forest (SchmidtVogt 2001). In traditional swidden landscapes, a mosaic of rotating patches of swiddens and swidden fallows in various stages of development is maintained in a continuous state of diversity and flux. In Southeast Asia, the first intensive studies of secondary vegetation communities in swidden fallows were carried out in the Philippines by Kowal (1966) on Luzon Island, and by Kellman (1969, 1970) on the Mt. Apo massif of Mindanao Island. Another important focus in Southeast Asia of research on biodiversity in swidden fallows is Papua New Guinea (Sillitoe 
1995; Bowman et al. 1990) With respect to the regional foci of this paper, northern Thailand and West Kalimantan, important contributions to our knowledge of biodiversity in fallow swiddens were made for West Kalimantan by Colfer et al. (1997), Lawrence (2004a, b), Lawrence et al. (1995), and Lawrence and Mogea (1996), and for northern Thailand by Lötsch (1958), Nakano (1978), Kunstadter 1978; Kunstadter et al. (1978a, b), Sabhasri (1978), and SchmidtVogt (1998, 1999).

Amazingly, fallows were once viewed as an acceptable, if "backward" way of restoring fertility, and they were often decried as "unproductive, unmanaged, and interesting only from the perspective of how [they] could be shortened" (Cairns 2007c). Recent research, however, has documented rich and diverse traditions of swidden-fallow management throughout Southeast Asia (Cairns 2007b). Management of fallows is often a complex, multi-year and multi-purpose process that commences as soon as farmers begin to clear new fields.

Trees, for instance, are frequently managed to promote rapid fallow regeneration during and after cropping (Zinke et al. 1978; Dove 1985; Mischung 1986; Schmidt-Vogt 2007; Yimyam 2006; Fukushima et al. 2008). A widely applied management practice is to cut trees, when clearing swiddens, at a height of $1.0-1.5 \mathrm{~m}$ and to leave the stumps so that sprouts may later grow from them. Some of the larger trees may be left standing as relict emergents, but are often pollarded to reduce shading of cultivated crops (Nyerges 1989). Both coppiced trees and relict emergents later contribute to the top canopy of secondary forest fallows. Schmidt-Vogt (2007) found through his research on relict emergents in swiddens of Lua farmers in northern Thailand that the frequency of species as relict emergents correlates well with the frequency of the same species in the coppice layer of swidden fallow forests as well as with their ecological importance in these forests in general. Relict emergents are in the literature sometimes referred to as "seed trees", suggesting that farmers consciously preserve these trees to assist regrowth of the forest (Santasombat 2003). Schmidt-Vogt (2007), however, was not able to substantiate this claim in his research. According to his informants, farmers left particular trees standing because their trunks were too thick or their wood too hard to cut easily. While the assumption that such trees enhance diversity of the plot directly, since they often represent species that do not appear in young regrowth, is not supported by some research, relict emergents may however, increase diversity by serving as early perching structures that encourage seed dispersers to visit. According to Salas (2006), Karen in northern Thailand cut off all branches except those at the top of the tree in order to attract birds.

The practice of leaving relict emergents during clearing as a management practice differs throughout Southeast Asia
(Kunstadter et al. 1978a, b; Mischung 1986; Schmidt-Vogt 2007). In Thailand, for example, the number of relict trees left by swiddeners varies by an order of magnitude. Some Lua' farmers were documented leaving over 200 trees per hectare (Kunstadter et al. 1978a, b; Schmidt-Vogt 2007), while Karen swiddeners were observed leaving only 20-40 per hectare (Schmidt-Vogt 1999). Dayaks in Indonesian and Malaysian Borneo generally leave far fewer relict trees, if any (Freeman 1955; Dove 1985; Lawrence 2004a). Dove (1985) suggested that the practice of leaving large trees may have been more common in earlier times but was waning in the 1970s, as the felling of younger forests, with fewer large hardwoods, became the norm among the Kantu' Dayaks. In addition, the increased availability of chainsaws (Mertz and Christensen 1997) may have encouraged the clearing of trees once considered too difficult to cut. The practice of leaving some relict emergents, however, does continue into the present, even in long-settled areas of Sarawak, where large trees or trees valuable for their timber or fruits continue to be left when swiddens are cleared (Burgers 2007).

Management is also done through planting, transplanting, weeding, and otherwise manipulating and/or enriching fallows with useful species-often woody species-over the years that the fallow develops. Some future fallow species are planted when the field is first made. For instance, in China's Yunnan province, the Hani/Akha have traditionally planted rattans into swiddens at the same time as they dibble in seeds of upland rice ( $\mathrm{Xu}$ 2007). While the grain crop ripens within several months, the rattan canes will remain part of the fallow until they are harvested after about 7 to 8 years. In Kalimantan, rubber is also interplanted with rice in similar ways and can remain part of a rubber-dominated fallow for decades (Peluso and Padoch 1996).

The issue of what length of fallow is adequate to restore the fertility of swidden soils has been widely researched, tested, and debated (Greenland 1975; Higgins et al. 1982; Roder et al. 1997). In contrast, studies of restoration of forest biodiversity and structure through fallowing have received less attention. Research done in Lua' communities in northern Thailand indicate that a fallow of 9-12 years is adequate for regeneration of complex stand structure and species composition (Sabhasri 1978; Schmidt-Vogt 1999). At one location in Chiang Mai province, forest fallows 710 years old included 66-77 tree species (Sabhasri 1978). Swidden fallow forests in the Lua village of Ban Tun in Mae Hong Son province exhibited three canopy layers and contained a total of 79 tree species. The most species rich stands had a total of 57-60 species including herbaceous plants and grasses, and of these 31 to 32 species in the tree layers on a $500 \mathrm{~m}^{2}$ plot (Schmidt-Vogt 1998, 1999). Recent comparative research on the development of tree species 
diversity on 1-, 3-, and 6-year old fallows of Karen and Lua villages in Mae Chaem district of northern Thailand documented an increase of tree species richness and diversity with fallow age from 1 year to 6 years. Another significant result is that species richness and species diversity in a 6year-old fallow in the Karen village, was higher than that found in a nearby control forest plot (Wangpakapattanawong and Schmidt-Vogt, unpublished data).

In a Dayak community of West Kalimantan, where coppicing and pollarding were less common, forest structure took longer to redevelop. Nevertheless, fallow tree diversity was still high, with 16 species $(>10 \mathrm{~cm}$ at breast height) per $1,000 \mathrm{~m}^{2}$ in a 6-year-old fallow $\left(1,000 \mathrm{~m}^{2}\right.$ was about one-tenth of the whole fallow). The number of tree species steadily increased with fallow age, and was ultimately found to be $60 \%$ higher in a 31 -year old fallow (26 species per 1,000 $\mathrm{m}^{2}$ ). Small tree diversity $(5-10 \mathrm{~cm}$ $\mathrm{dbh}$ ) was also high and increased with age (13 to 21 species per $200 \mathrm{~m}^{2}$ ). Most importantly, at least $40 \%$ of the small tree species were not represented among the larger trees at the same location, indicating very high local diversity. These data from Thailand and Indonesia demonstrate that substantial early fallow richness can increase considerably as the fallow ages.

Although a shorter fallow period would severely reduce tree species diversity, even a 6- or 7-year-old woody fallow can host substantial diversity (see above), at least within a matrix of fallows of many ages. Some of this diversity is a result of mosaic landscapes that include young and old fallows, and managed and unmanaged forest. In a review paper on the conservation value of swidden cultivation landscapes, Finegan and Nasi (2004) pointed out that the capacity of swidden landscapes to maintain biodiversity is mainly due to their mosaic character. The secondary forest components, especially mature secondary forests, play an especially important role because of their significance for forest-dependent and interior species. In a matrix composed exclusively of young fallows, many of the species currently observed would not have time to achieve reproductive status. The diversity of young fallows, in a sea of other young fallows, would be limited by the pool of species capable of producing seeds in surrounding patches (Lawrence 2004a, b).

The role of animals in the regeneration of swidden fallows is still poorly understood, mainly due to a lack of research on animal biodiversity in swidden landscapes. Recent research on indigenous knowledge among swiddeners in northern Thailand concerning regeneration in swidden fields highlighted the importance of birds as seed dispersers (Wangpakapattanawong, Schmidt-Vogt, unpublished data). A survey of bird biodiversity in swidden fallows of Xishuangbanna in Yunnan showed that there is far greater bird species richness and diversity in an environment under traditional swidden management than in a swidden system in transition characterized by shortened fallow periods. The greater bird biodiversity in the traditional swidden system was explained by the structural complexity-especially of the later fallow forest stages — which provided a wide range of habitat niches, and by greater overall habitat heterogeneity, and it certainly has an effect on the regeneration of plant species (Wang and Young 2003).

Repeated shorter fallow cycles can result in severe soil degradation and grassland formation including bamboodominated fallows, particularly if a field is subjected to frequent fires or grazing (Conklin 1959; Durno et al. 2007; Nikolic et al. 2008). Degradation causes a decline in diversity along with a change in vegetation structure that can result in feedbacks that further erode diversity. In the case of a Karen community of Chiang Mai province, where fallow periods have been reduced to about 5 years, fallow forests have been replaced by a dominant and invasive weed, Chromolaena odorata, with poor fallow biomass productivity (Nakano 1978). Increasingly, the landscapes of swidden in transition comprise younger and less speciesrich fallows. Maintenance of fallow diversity under such conditions will most likely require active management by farmers.

Some groups in Southeast Asia are known to manage weedy species in fallows, including those dominated by aggressive shrubs, such as Austroeupatorium inulaefolium, found at altitudes above $200 \mathrm{~m}$ asl in Sumatra (Cairns $2007 \mathrm{a}, \mathrm{b}, \mathrm{c})$. This multipurpose invasive weed has a large number of economic uses; and it is believed to improve growing conditions in swiddens. Minangkabau farmers often propagate Austroeupatorium in their fallows through cuttings, and maintain the stands once they are established (Cairns 2007a, b, c). We note that the practice of managing weedy or invasive species may actually diminish the plant diversity of fallows if the species is aggressive enough to outcompete other species.

However, this is not always the case. For instance, $M$. denticulata is associated with up to 30 species of mycorrhizal fungi, critical to nutrient cycling (Youpensuk et al. 2005; Yimyam et al. 2008). This association highlights the complex interactions that add another layer of biodiversity in swidden systems. H'tin, Khamu and Karen farmers in Thailand believe that the pioneering tree Macaranga denticulata (Euphorbiaceae) also has fallowenriching properties. Good upland rice yields $(3.5 \mathrm{t} / \mathrm{ha}$ or higher) on the poorest mountain soils ( $\mathrm{pH} 4.0,2 \mathrm{ppm}$ available $\mathrm{P}$ ) have been reported when high density stands of M. denticulata (42,000 trees/ha) appear in short fallows (Yimyam et al. 2003). In such a system of decreasing fallow periods, already reduced to 6 years or less, the rich diversity of swidden crops has been maintained for the past 10 years. 
Many of the species that grow and are managed in swidden fallows provide food, medicines, and building materials that support swiddening households and communities and are frequently marketed in towns and cities in both mainland and insular Southeast Asia (Kunstadter 1978; Mertz 2007; Burgers 2007; Fu et al. 2003; Sturgeon 2005). In the first years of the fallow, species of planted vegetables and other crops often remain despite the growth of spontaneous vegetation (e.g., Tayanin 2007). As fallows age, naturally regenerated and subsequently managed ferns, vines, bamboos, fruits, and other young secondary forest products become increasingly important. Kunstadter (1978) found that the succession of plant communities was paralleled by a succession of products: while the herbdominated early successional stages were a source mainly of medicinal plants, the secondary forest stages yielded mainly wood and wild food plants. In the village of Pa Pae, the majority of species of the altogether 295 food plants, 119 medicinal plants, 44 plant species used for weaving and dyeing, and the 27 fuel plants were derived from fallow swiddens (Kunstadter 1978; Kunstadter et al. 1978a, b). In one Akha-Hani village in China's Yunnan province, researchers found that 76 species of useful plants were harvested from 7 hectares of swidden fallows of varying ages (Fu et al. 2003). In West Kalimantan, data gathered in 11 swidden fallows belonging to residents of one village showed that the vegetation of older, tree-dominated fallows also had considerable economic value; more than half the individual trees and at least $30 \%$ of the tree species were found to be economically useful (Lawrence et al. 1995; Vandermeer et al. 2002). Researchers have suggested that intensely managed fallows represent a promising way to increase incomes, improve diets, and increase labor productivity among swidden cultivators (Mertz 2007; Burgers 2007; Fu et al. 2003; Colfer 2008; Colfer et al 1997; Cairns 2007a, b, c). The elimination of fallows when swiddening is replaced by permanent croppingespecially by monocultural plantations of export crops - may markedly downgrade diversity, and with it nutritional status, health, and incomes of smallholder households, as swidden fallows often function as "safety-nets" for the rural poor (Burgers 2007; Mertz 2007; Johns 2007; Sturgeon 2005).

In short, considerable agricultural as well as wild biodiversity is maintained, managed, and utilized in traditional swidden ecosystems with fallows of sufficient length that allow the complexity of secondary forests and preceding successional stages to be regained in terms of both floristics as well as structure. On the other hand, shortening the length of the fallow can lead to the loss of some slow regenerating species or the development of a herbaceous fallow. Both cases equate to a loss of biodiversity. If this occurs across an entire landscape, the loss would be significant.

\section{Crop Substitution, Transformation of Swidden, and Loss of Biodiversity}

Among the many drivers that are leading to the replacement of swidden cultivation by other land uses in montane mainland Southeast Asia are government policies directed at eradicating the opium poppy (McCoy 1972; Sturgeon 2005).

Opium has been grown in the region in both homegardens and swidden fields, but production has been largely associated with highland swiddens. Starting in the late 1960s international pressure was brought to bear on governments in the mountainous "Golden Triangle" to eliminate opium cultivation. External support poured in to both institute crop substitution programs and to improve the infrastructure and marketing needed to support production and marketing of the new crop alternatives. Despite the fact that many swiddeners in the region never grew any opium poppies, a connection was drawn between the illegal crop and the farming system that supported it. Programs to eliminate opium cultivation provided an important entry point or first step towards stopping swidden agriculture altogether. Following the eradication of opium cultivation in many areas, the process of crop substitution inexorably led to widespread intensive farming of cash crops, in place of all types of swiddening.

With infrastructure development, improved communication and transportation networks, the intrusion of external markets has become another major force transforming traditional swidden areas into landscapes dominated by cash cropping, including intensive farming of annual and perennial plantation crops (Rigg 2002). In China's Yunnan province where opium was eradicated in 1949, the government offered alternative development featuring many annual and perennial cash crops including industrial crops produced in plantations (Sturgeon 2005).

Transfers of large-scale production of many cash and industrial crops between the countries in the region have become an important factor in the replacement of swiddens, and related patterns of agrobiodiversity change. Throughout montane mainland Southeast Asia, rubber is increasingly occupying the mountain landscapes (Thongmanivong et al. 2005; Xu 2006; Manivong and Cramb 2008; Ziegler et al. 2009a). The scale of these monoculture systems has virtually wiped out the agrobiodiversity that once flourished in swidden fields and is contributing to the loss of high diversity rain forest (Li et al. 2007; Qiu 2009). In insular Southeast Asia many industrial and export crops, including rubber, palm oil, cloves and black pepper are produced in both large- and small-scale production units, sometimes with government encouragement and often without, and in a variety of systems (Cramb et al. 2009; Koh and Wilcove 2008; McMorrow et al. 2001). 
However, even in Sumatra and Kalimantan, where 'jungle rubber' is a relatively species-rich production system (Gouyon et al. 1993; Michon and DeForesta 1991; Lawrence 1996), the loss of biodiversity following conversion from swidden is highly significant. The effects of more intensive management and focus on a single cash crop are apparent at the scale of an entire landscape. Swidden fallows generally feature four times as many tree species as do rubber gardens (i.e., 161 vs. 40 species sampled across the landscape in eleven $1,000 \mathrm{~m}^{2}$ plots each, Fig. 1, after Lawrence 2004b). At the plot scale, rubber gardens in West Kalimantan also show lower diversity, with a maximum of 15 species and a mean of 6 tree species per $1,000 \mathrm{~m}^{2}$ (vs. a maximum of 42 and a mean of 22 for similarly aged fallows) (Fig. 1). The negative effects on diversity of the transition to rubber would probably be much more evident if herbs, epiphytes and other small lifeforms were considered.

Timber-focused reforestation programs have also been instrumental in replacing diverse swiddens with monocultures or near monocultures. In Luang Prabang province of Laos, for example, teak plantations have been among the most widely accepted alternatives to swidden cultivation in ethnic minority communities over the past 20 years, especially among the Khamu ethnic group (Hansen et al.

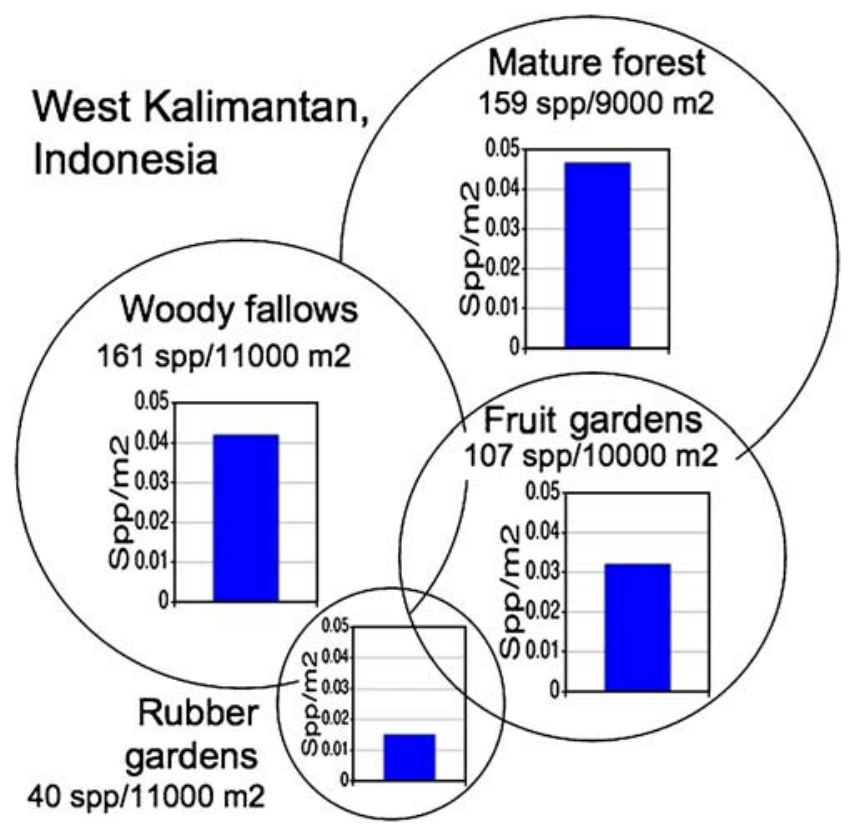

Fig. 1 Diversity of trees under shifting cultivation in West Kalimantan, Indonesia by land use type. Circles represent cumulative diversity of trees $>10 \mathrm{~cm}$ dbh sampled in plots across the landscape $(n=10-11$ for managed forests, and $n=3$ for mature forest). Circles and are sized to show landscape-scale differences in the species pool associated with each forest type (relative number of species per square meter sampled). Inset charts for each land use type show maximum plotlevel diversity, in species per square meter sampled to account for different plot sizes between secondary $\left(1,000 \mathrm{~m}^{2}\right)$ and mature/ conservation forests $\left(750 \mathrm{~m}^{2}\right)$
2007). Smallholder teak production is now economically profitable for some former swiddeners, but other impacts of the change to managing monocultural plantations in landscapes that formerly featured a diversity of land uses and considerable biodiversity is yet to be investigated. Data from other Southeast Asia regions show, however, that timber production need not result in extreme losses of biological diversity. Trees producing timber and/or oils such as illipe (Shorea spp.) or resins such as damar (resins of Shorea spp.) have been cultivated in multi-species agroforests for decades in Indonesia and Malaysia (Michon et al. 1986; Michon and de Foresta 1999; Peters 2003; Padoch and Peters 2003). Some of these systems developed locally in swiddening communities and some have been encouraged by NGOs (Cairns 2007a, b, c). It is not clear, however, how widespread the transition to timber farming is in insular Southeast Asia and what its overall impact on biodiversity in former swidden areas will be. Impacts on diversity will depend on the level and kind of management that is applied or permitted in plantations, that is, how many 'weed' trees will be allowed to flourish in the understory and how many non-timber species will be planted and/or managed. Weed trees may provide subsistence products (like fuelwood or medicines) and may provide early economic returns if the markets exist and are accessible; communities on paved roads may therefore be more likely to have species-rich timber plantations.

In short, where national and international policy have played important roles in the recent past (as in the opiumgrowing areas of mainland Southeast Asia), regional economic development programs have largely transformed the complex and biodiverse landscapes of swidden and forest fallows to simplified landscapes of monocultural plantations of commercial crops on a large scale. The change to commercial crops and plantations in some cases has led to a total loss of the diversity associated with management in former swidden fields (Sutthi 1989). But the losses may not always be so dire. With appropriate infrastructure and markets, somewhat more diverse but highly profitable agroforestry systems may also be preserved and promoted (see fruit gardens, Fig. 1). These systems can and do sustain some of the diversity found in the fallow phase of swiddens. Even without external incentives, many farmers succeed in rescuing valuable portions of the diversity once found in their swidden fields and fallows.

\section{Rescuing the Biodiversity of Swidden Ecosystems}

Landscape mosaics are common in areas of Southeast Asia where swiddening is practiced (Fox and Vogler 2005; Fox et al. 2000; Ziegler et al. 2004; Sturgeon 2005). In the case of Tee Cha village in Mae Hong Son district of northern 
Thailand, the landscape is composed of swidden fields currently in crops, fallow fields of different ages, paddy terraces, mixed orchards, home gardens, protected conservation forests, and community forests managed for fuelwood, timber, and various other uses (Fig. 2). Each land use type in the mosaic includes characteristic and dissimilar combinations of domesticated, semi-domesticated and wild species. While a complete conversion of mountain landscapes to cash and industrial crops is occurring in many places of mainland Southeast Asia, in many more places, industrial crops are grown alongside more traditional land use types: rice paddies, multi-purpose and conservation forests as well as remaining swiddens and swidden fallows. These mixed landscapes are often venues for maintaining and even enhancing biodiversity.

As their swidden cultivation systems are inexorably changed and disappear, some Hmong, Lahu and Akha-Hani farmers in northern Thailand are increasingly managing
Fig. 2 Map of land use in Tee Cha village of Mae Hong Son province, Thailand

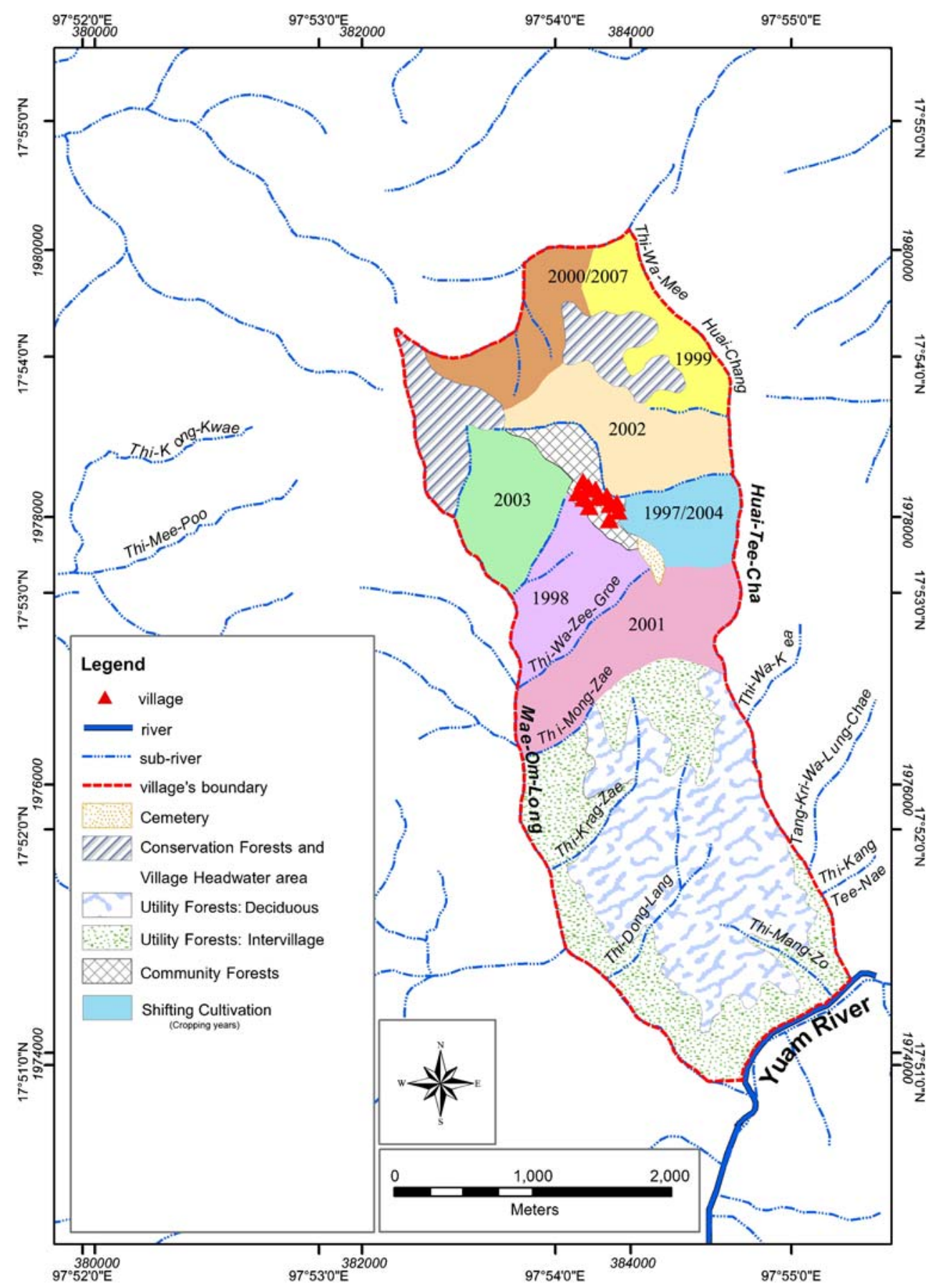


elaborate homegardens that harbor many upland crops formerly found in swidden fields ( $\mathrm{Fu}$ et al. 2003) and actively rescuing valued biodiversity from former swidden fields and fallows. Headwater and other conservation forests, including holy hills and sacred forests, are other venues for such preservation (Pei 1993). Because exploitation is often strictly regulated, these conservation areas can and have become reservoirs for diverse species that were once more widespread across the landscape, including in now-disappeared swiddens and fallows. Such managed forests may even be more diverse than unmanaged forests. In Daka, a Hani/Akha village in Yunnan province for example, the community has enriched biodiversity by allowing medicinal practitioners to "cultivate" a small portion of the headwater forest (Fu et al. 2008). Twice as many plant species were found in medicinal plots as in the surrounding forests; nine of these species are listed as endangered. In West Kalimantan, the richest managed forests had tree diversity similar to that of the richest patches of conservation forest, albeit on a very small spatial scale. Swidden fallows were richer than the more intensively managed fruit gardens and approached the level of mature conservation forest (insets of species richness per square meter, Fig. 1, after Lawrence and Mogea 1996). When assessing larger areas or including smaller trees, conservation forests are significantly more diverse, but the small-scale forest plots of a swidden landscape do have the potential to retain ecological communities of similar complexity (and perhaps function) as mature forests.

Home gardens and field edges are two other landscape components where agrobiodiversity is rescued. Hmong, Lahu, and Akha-Hani farmers in northern Thailand, are increasingly managing elaborate home gardens that harbor many upland crops formerly found in swidden fields ( $\mathrm{Fu}$ et al. 2003). In one Hmong village in northern Thailand, some farmers who have lost their swidden plots have begun to cultivate the margins of their crop fields (edges) with useful spontaneous species as well as traditional crops from former swidden fields (Rerkasem, unpublished data). These plantings provide food, medicine, and other necessities and some have found ready markets for these additional products among the urban Hmong community in the city of Chiang Mai. The governing body of the village has incorporated the enriched "edges" into the communal conservation forest, allowing individual farmers to continue their cultivation of wild species and hence continue to maintain and even enhance local biodiversity. In Yunnan province, the Akha-Hani farmers of Daka village mentioned above have also begun moving fallow species into permanent cultivation in homegardens and elsewhere as they lose access to areas for making swiddens and for collecting wild vegetables (Fu et al. 2003). Some research has found that women play a leading role in this transfer of useful wild plants from the fallows to the fields and gardens (Price and Ogle 2008). As swiddens change and fallow period and area are reduced, patterns of preservation of plants within cultivated fields also shift. Wild useful plants are often left in the crop fields, including a variety of tubers, other wild edible vegetables, and plants with many other uses. Special care is taken not to remove species recognized not only for their direct uses but also for their fallow-enriching properties, such as mimosa (Mimosa invisa), a cover crop in rotation with cash crops such as cabbage and maize in northern Thailand. Farmers manage this species by collecting the seeds and sowing them in areas where the mimosa is absent.

\section{Conclusions}

High levels of both spontaneous biodiversity and agricultural biodiversity are associated with traditional swidden agriculture in Southeast Asia. This diversity is, in part, the product of constant innovations by farm households and communities striving to meet economic, ritual and social needs in a highly diverse and changing environment. Although swiddening has been evolving in the region for millennia, myriad factors including increasing market and political integration over the past 50 years have brought rapid region-wide changes. In particular, government incentives to eradicate the cultivation of opium poppy in the Golden Triangle, together with general policies aimed at eliminating swidden agriculture throughout Southeast Asia, have threatened many forest and crop species - including rice, the world's most important food crop, at its center of diversity. Ironically, some of the greatest losses of agrobiodiversity have resulted from national directives aimed directly at conserving biodiversity. Increased integration into markets also often appears to be detrimental to diversity in traditional land use systems, since it often results in monocultural plantations, and yet market forces do not always lead to drastic losses of biodiversity. While the ongoing swidden transformations have generally affected crop and fallow biodiversity negatively in obvious and expected ways, in some cases the effects have been ambiguous or even contradictory. Loss of diversity at one level may be offset as plant diversity is rescued within homegardens, field edges, agroforests, and conservation forests.

As swidden farming declines, systems are being transformed to other land uses in novel ways; landscapes and familiar field types are being reconfigured. Rich agrobiodiversity from swidden fields is sometimes lost completely when they are transformed to monocultures. In other cases threatened plant diversity is incorporated into other field types, such as homegardens and field "edges". Biodiversity serves multiple purposes for the farming households of the region. These needs are typically not 
incorporated into national and regional development plans. Management and conservation of the agrobiodiversity associated with swidden systems has been dependent on a myriad set of local rules, practices and the operation of informal networks. Since local networks of seed exchange systems are one of the important mechanisms that maintain and conserve genetic diversity in rice, better understanding of these still little-studied systems would help to promote and/or sustain on-farm conservation of crop genetic resources. The collapse of these networks could have substantial negative impacts on agrobiodiversity on a large scale including the total loss of crop genetic resources of enormous value. A stronger focus on the scalar effects of exchange linkages on diversity is important, as exchanges outside a local area may result in homogenization of genetic diversity at a regional scale.

Understanding of the dynamic processes of the management of agrobiodiversity- including diversity in swidden fallows- as Southeast Asian landscapes are transformed is clearly inadequate. This shortcoming may be partly due to the lack of fundamental research. It may also be due to the "invisibility" of these refuges of biodiversity: many of the most diverse and dynamic ecosystems are not readily observable in limited field visits, especially when the agricultural expertise of swiddeners is neither appreciated nor acknowledged. Rich agrobiodiversity is often managed outside agricultural lands, at a variety of spatial scales related to both farmer incentives and market forces. New approaches and methods are needed to support interdisciplinary research on the decline, maintenance, and transformation of crop and fallow biodiversity in the region. Finally, although the biodiversity that was once a widespread feature of swidden landscapes throughout Southeast Asia is threatened, it is neither declining at a uniform rate, nor is its future completely bleak. Understanding how diversity, both crop and wild, has been maintained in swidden landscapes despite recent social, economic, and political changes will help conserve the remaining biodiverse ecosystems of Southeast Asia.

\section{References}

Anderson, E. F. (1993). Plants and People of the Golden Triangle: Ethnobotany of the Hill Tribes of Northern Thailand. Silkworm Books (Thailand Edition), Bangkok.

Bellon, M. R. (1996). The Dynamics of Crop Infraspecific Diversity: A Conceptual Framework at the Farmer Level. Economic Botany 50: 26-39.

Boonwaat, L. (2000). Planning and Implementation of Kyson Project Activities. Report of a Seminar on Alternative Socio-Economic Development to Replace Opium Poppy Cultivation. United Nations International Drug Control Programme and Vienamese National Drug Control Committee, Hanoi, pp. 20-27.
Bowman, D. M. J. S., Woinarski, J. C. Z., Sands, D. P. A., Wells, A., and McShane, V. J. (1990). Slash-and-Burn Agriculture in the Wet Coastal Lowlands of Papua New Guinea: Response of Birds, Butterflies and Reptiles. Journal of Biogeography 17: 227-239. doi: $10.2307 / 2845121$.

Brookfield, H., Padoch, C., Parson, H., and Stocking, M. (2003). Cultivating Biodiversity: Understanding, Analysing and Using Agricultural DiversityIntermediate Technology Development Group, London, p. 292.

Brush, S. B. (2004). Farmers' Bounty: Locating Crop Diversity in the Contemporary Worlds. Yale University Press, New Haven.

Bruun, T. B., De Neergaard, A., Lawrence, D., Ziegler, A. D. (2009). Environmental Consequences of the Demise in Swidden Agriculture in SE Asia: Soil Nutrients and Carbon Stocks. Human Ecology, this issue.

Burgers, B. (2007). Commercialization of fallow species by Bidayuh shifting cultivators in Sarawak, Malaysia. In Cairns, M. (ed.), Voices from the Forest: Integrating Indigenous Knowledge into Sustainable Upland Farming. Resources for the Future, Washington, DC, pp. 87-95.

Cairns, M. (2007a). Management of fallows based on Austoeupatorium inulaefolium by Minangakabau farmers in Sumatra, Indonesia. In Cairns, M. (ed.), Voices from the Forest: Integrating Indigenous Knowledge into Sustainable Upland farming. Resources for the Future, Washington, DC, pp. 153-184.

Cairns, M. (ed.) (2007b). Voices from the Forest: Integrating Indigenous Knowledge into Sustainable Upland Farming, Resources for the Future, Washington, DC.

Cairns, M. (2007c). Conceptualizing indigenous approaches to fallow mamanegement: A road map to the volume. In Cairns, M. (ed.), Voices from the Forest: Integrating Indigenous Knowledge into Sustainable Upland Farming. Resources for the Future, Washington, DC, pp. 16-36.

Chang, T. T. (1976). The Origin, Evolution, Cultivation, Dissemination and Diversification of Asian and African Rices. Euphytica 25: 425-441. doi:10.1007/BF00041576.

Chansina, K., Chareonwatana, T., McArthur, H., Phongtha, B., and Uhara, G. (1991). The agroecosystem of Ban Semoun. In: Report of a workshop on Swidden Agroecosystems in Sepone District, Savannakhet province, Lao PDR, The SUAN Secretariat, pp. 25-43.

Coffey, K. (2008). Evolution in Complex Social Systems: The Dynamics of Smallholder Rice Production in Northern Thailand. Unpublished Ph.D. Dissertation, Columbia University. Department of Ecology, Evolution, and Environmental Biology.

Colfer, C. J. P. (2008). The Longhouse of the Tarsier, Changing Landscapes, Gender, and Wellbeing in Borneo. Borneo Research Council, Philipps, Maine.

Colfer, C. J. P., and Dudley, R. G. (1993). Shifting Cultivators of Indonesia: Managers or Marauders of the Forest? Rice Production and Forest Use Among the Uma' Jalan of East Kalimantan. Food and Agriculture Organization of the United Nations, Rome.

Colfer, C. J. P., and Soedjito, H. (2003). Food, forest, and fields in a Bornean rain forest: Toward appropriate agroforestry development. In Padoch, C., and Peluso, N. (eds.), Borneo in Transition: People, Forests, Conservation and Development. Oxford University Press, Kuala Lumpur, pp. 215-223.

Colfer, C. J. P., Peluso, N. L., and Chung, C. S. (1997). Beyond Slash and Burn: Building on Indigenous Management of Borneo's Tropical Rain Forests. New York Botanical Garden, Bronx, N.Y..

Conklin, H. C. (1957). Hanunoo Agriculture: A Report on an Integral System of Shifting Cultivation in the Philippines. FAO, Rome.

Conklin, H. C. (1959). Shifting cultivation and succession to grassland climax. In: Proceedings of the Ninth Pacific Science Congress, 1957, Vol. 7, pp. 191-221. Bangkok.

Conklin, H. C. (1963). The Study of Shifting Cultivation. Pan American Union, Washington. 
Cramb, R. A. (2007). Land and Longhouse: Agrarian Transformation in the Uplands of Sarawak. NIAS Press, Copenhagen.

Cramb, R. A., Colfer, C. J. P., Dressler, W., Laungaramsri, P., Le Quang Trung, Mulyoutami, E., Peluso, N. L., Wadley, R. L. (2009). Swidden Transformations And Rural Livelihoods In Southeast Asia. Human Ecology. doi:10.1007/s10745-009-9241-6.

Crooker, R. A. (1986). Opium Production in Northern Thailand: A Geographical Perspective. Unpub. Ph.D. Diss. University of California-Riverside.

Delang, C. O. (2002). Deforestation in Northern Thailand: The Result of Hmong Swidden Farming Practices or Thai Rural Development Strategies? Society and Natural Resources 15: 483-501. doi:10.1080/08941920290069137.

Dove, M. R. (1985). Swidden Agriculture in Indonesia. Mouton, Berlin.

Durno, J. L., Deetes, T., and Rajchaprasit, J. (2007). Natural forest regeneration from an Imperata Fallow. In Cairns, M. (ed.), Voices from the Forest: Integrating Indigenous Knowledge into Sustainable Upland Farming. Resources for the Future, Washington, DC, pp. $122-136$.

Evrard, O. (2006). Chroniques Des Cendres: Anthropologie Des Societes Khmou Et Dynamiques Interethniques Du Nord-Laos. IRD Editions, Paris.

FAO (2009). FAOSTAT. http://faostat.fao.org/.

Finegan, B., and Nasi, R. (2004). The biodiversity and conservation potential of shifting cultivation landscapes. In Schroth, G., da Fonseca, G. A. B., Harvey, C. A., Gascon, C., Vasconcelos, H. L., and Izac, A.-M. N. (eds.), Agroforestry and Biodiversity Conservation in Tropical landscapes. Island, Washington, DC, pp. 153-197.

Forsyth, T., and Walker, A. (2008). Forest Guardians, Forest Destroyers: The Politics of Environmental Knowledge in Northern Thailand. University of Washington Press, Seattle, London.

Fox, J., and Vogler, J. B. (2005). Land-Use And Land-Cover Change in Montane Mainland Southeast Asia. Environmental Management 36 (3): 394-403. doi:10.1007/s00267-003-0288-7.

Fox, J., Truong, D. M., Rambo, A. T., Tuyen, N. P., Cuc, L. T., and Leisz, S. (2000). Shifting Cultivation: A New Old Paradigm for Managing Tropical Forests. Bioscience 50 (6): 521-528.

Fox, J., Fujita, Y., Ngidang, D., Peluso, N., Potter, L., Sakuntaladewi, N., Sturgeon, J. and Thomas, D. (2009). Policies, politicaleconomy, and swidden in Southeast Asia. Human Ecology, this issue.

Freeman, D. (1955). Iban Agriculture: A Report on the Shifting Cultivation of Hill Rice by the Iban of Sarawak. H.M. Stationery Office, London.

Fu, Y., Guo, H., Chen, A., Cui, J., and Padoch, C. (2003). Relocating Plants from Swidden Fallows to Gardens in Southwestern China. Economic Botany 57 (3): 389-402. doi:10.1663/0013-0001 (2003)057[0389:RPFSFT]2.0.CO;2.

Fu, Y., Chen, J., Guo, H., Chen, A., and Cui, J. (2008). Utilisation and Conservation Strategies for Plant Resources in Tropical Montane Agroecosystems: A Case Study from Xishuangbanna, SW China. International Journal of Biodiversity Science and Management 4 (1): $32-43$.

Fukushima, M., Kanzaki, M., Hara, M., Ohkubo, T., Preechapanya, P., and Choocharoen, C. (2008). Secondary Forest Succession After the Cessation of Swidden Cultivation in the Montane Forest Area in Northern Thailand. Forest Ecology and Management 255: 1994-2006. doi:10.1016/j.foreco.2007.12.022.

Gouyon, A., De Foresta, H., and Levang, P. (1993). Does 'Jungle Rubber' Deserve its Name? An Analysis of Rubber Agroforestry Systems in Southeast Sumatra. Agroforestry Systems 22: 181206. doi:10.1007/BF00705233.

Greenland, D. J. (1975). Bringing the Green Revolution to the shifting cultivator. Science 190: 841-844.

Guo, H., Padoch, C., Coffey, K., Chen, A., and Fu, Y. (2002). Economic Development, Land Use and Biodiversity Change in the Tropical Mountains of Xishuangbanna, Yunnan, Southwest China. Environmental Science and Policy 5 (6): 471-479. doi:10.1016/S1462-9011(02)00093-X.

Hansen, P. K. (1995). Shifting Cultivation Adaptations and Environment in a Mountainous Watershed in Northern Thailand. Unpublished PhD-thesis. Royal Veterinary and Agricultural University, Copenhagen, Denmark.

Hansen, P. K., Sodarak, H., and Savathong, S. (2007). Teak production by shifting cultivators in northern Lao P.D.R. In Cairns, M. (ed.), Voices from the Forest: Integrating Indigenous Knowledge into Sustainable Upland farming. Resources for the Future, Washington, DC, pp. 414-424.

Higgins, G. M., Kassam, A. H., Naiken, A. H., Fisher, L., and Shah, M. M. (1982). Potential Population Supporting Capacities of Lands in the Developing World. Technical Report INT/74/P13. FAO, Rome.

IRRI (2008). IRRI World Rice Statistics. http://www.irri.org/science/ ricestat/data/may2008/WRS2008-Table34.pdf

Jarvis, D. I., Padoch, C. and Cooper, H. D. (2007). (eds.) Managing Biodiversity in Agricultural Ecosystems. Columbia University Press: New York.

Johns, T. (2007). Agrobiodiversity, diet and human health. In Jarvis, D. I., Padoch, C., and Cooper, H. D. (eds.), Managing Biodiversity in Agricultural Ecosystems. Columbia University Press, New York.

Kellman, M. C. (1969). Some Environmental Components of Shifting Cultivation in Upland Mindanao. Journal of Tropical Geography 28: $40-56$.

Kellman, M. C. (1970). Secondary Plant Succession in Tropical Montane Mindanao. Australian National University, Canberra.

Koh, L. P., and Wilcove, D. S. (2008). Is oil palm agriculture really destroying tropical biodiversity? Conservation Letters 1:60-64.

Kowal, N. E. (1966). Shifting Cultivation, Fire and Pine Forest in the Cordillera Central, Luzon, Philippines. Ecological Monographs 36 (4): 389-419.

Kunstadter, P. (1978). Ecological modification and adaptation: an ethnobotanical view of Lua' Swiddeners in Northwestern Thailand. In Ford, R. I. (ed.), The Nature and Status of Ethnobotany. Michigan University, Ann Arbor, Michigan, pp. 168-200.

Kunstadter, P., Sabhasri, S., and Smitinand, T. (1978a). Flora of a Forest Fallow Farming Environment in Northwestern Thailand. Journal of the National Research Council of Thailand 10 (1): 1-45.

Kunstadter, P., Chapman, E. C., and Sabhasri, S. (1978b). Farmers in the Forest: Economic Development and Marginal Agriculture in Northern Thailand. The University Press of Hawaii, Honolulu.

Lawrence, D. C. (1996). Trade-Offs Between Rubber Production and Maintenance of Diversity: The Structure of Rubber Gardens in West Kalimantan, Indonesia. Agroforestry Systems 34 (1): 83100.

Lawrence, D. (2004a). Erosion of tree Diversity over 200 Years of Long-Fallow Shifting Cultivation in Indonesia. Ecological Applications 14: 1855-1869.

Lawrence, D. (2004b). Land-use change, biodiversity and ecosystem functioning in West Kalimantan. In Gerold, G., Fremery, M., and Guhardja, E. (eds.), Land Use, Nature Conservation and the Stability of Rainforest Margins in Southeast Asia. Springer, Berlin, pp. 253-268.

Lawrence, D. (2005). Biomass Accumulation After 10 to 200 years of Shifting Cultivation in Bornean Rainforest. Ecology 86: 26-33.

Lawrence, D. C., and Mogea, J. P. (1996). A Preliminary Analysis of Tree Diversity in the Landscape Under Shifting Cultivation North of Gunung Palung National Park. Tropical Biodiversity 3: 297-319.

Lawrence, D. C., Leighton, M., and Peart, D. R. (1995). Availability and Extraction of Forest Products in Managed and Primary Forest Around a Dayak Village in West Kalimantan, Indonesia. Conservation Biology 9 (1): 76-88. 
Li, H., Aide, T. M., Ma, Y., Liu, W., and Cao, M. (2007). Demand for Rubber is Causing the Loss of High Diversity Rain Forest in SE China. Biological Conservation 16: 1731-1745.

Lötsch, F. (1958). Der Einfluss des Brandrodungsbaues auf das Gefüge des Tropenwaldes und die Wasserführung der Ströme, untersucht am Beispiel Nordthailands. Erdkunde 12: 182-205.

Manivong, V., and Cramb, R. A. (2008). Economics of Smallholder Rubber Expansion in Northern Laos. Agroforestry Systems 74: $113-125$.

Maxted, N., Ford-Lloyd, B., and Hawkes, J. G. (1997). Plant Genetic Conservation: The In Situ Approach. Chapman and Hall, London.

McCoy, A. W. (1972). The politics of heroin in Southeast Asia. HarperCollins: New York.

McMorrow, J., and Talip, M. A. (2001). Decline of forest area in Sabah, Malaysia: relationship to state policies, land code, and land capability. Global Environmental Change 11: 217-230.

Mertz, O. (2007). The potential of wild vegetables as permanent crops or to improve fallows in Sarawak, Malaysia. In Cairns, M. (ed.), Voices from the Forest: Integrating Indigenous Knowledge into Sustainable Upland Farming. Resources for the Future, Washington, DC, pp. 73-86.

Mertz, O., and Christensen, H. (1997). Land Use and Crop Diversity in Two Iban Communities, Sarawak, Malaysia. Geografisk Tidsskrift-Danish Journal of Geography 97: 98-110.

Mertz, O., Padoch, C., Fox, J., Cramb, R. A., Leisz, S. J., Nguyen, T. L., and Vien, T. D. (2009). Swidden change in Southeast Asia: understanding causes and consequences. Human Ecology. doi:10.1007/s10745-009-9245-2.

Michon, G., and DeForesta, H. (1991). Complex agroforestry systems and the conservation of biological diversity (I): Agroforests in Indonesia: the link between two worlds. In Proceedings of the International Conference on Tropical Biodiversity 'In Harmony with Nature,' 12-16 June 1990, Kuala Lumpur, Malaysia, pp. 457-473. Malayan Nature Society.

Michon, G., and de Foresta, H. (1999). Agro-forests: incorporating a forest vision in agroforestry. In Buck, L. E., Lassoie, J., and Fernandes, E. C. M. (eds.), Agroforestry in Sustainable Agricultural Systems. CRC, Washington D.C., pp. 381-406.

Michon, G., Mary, R., and Bompard, J. (1986). Multistoried Agroforestry Garden System in West Sumatra, Indonesia. Agroforestry Systems 4: 315-338.

Mischung, R. (1986). Environmental "Adaptation" among upland peoples of northern Thailand. A Karen/Hmong case study. Final report, National Research Council Thailand, Bangkok.

Morishima, H., Sano, S., and Oka, H. I. (1980). Observation on Wild and Cultivated Rices and Companion Weeds in the Hilly Area of Nepal, India and Thailand. Report of a Study Tour in Tropical Asia, 1979. National Institute of Genetics, Mishima, Japan.

Mounmeuangxam, K. (2003). Rice Diversity and Farmers' Management in Houaphanh Province of the Lao PDR. Chiang Mai University, Chiang Mai.

Nakano, K. (1978). An Ecological Study of Swidden Agriculture at a Village in Northern Thailand. Tonan Ajia Kenkyu (Southeast Asian Studies) 18: 40-67.

Nazarea, V. D. (2006). Local Knowledge and Memory in Biodiversity Conservation. Annual Review of Anthropology 35: 317-335.

Nikolic, N., Schultze-kraft, R., Nicolic, M., Böcker, R., and Holz, I. (2008). Land Degradation on Barren Hills: A Case Study in Northeast Vietnam. Environmental Management 42: 19-36.

Nye, P. H., and Greenland, D. J. (1960). The Soil Under Shifting Cultivation. Technical Communication No. 51. Commonwealth Agricultural Bureaux. Farnham Royal, Bucks, England.

Nyerges, A. E. (1989). Coppice Swidden Fallows in Tropical Deciduous Forest: Biological and Technological, and Sociocul- tural Determinants of Secondary Forest Successions. Human Ecology 17: 379-400.

Padoch, C. (1985). Labor Efficiency and Intensity of Land Use in Rice Production: An Example from Kalimantan. Human Ecology 13: 271-289.

Padoch, C., and Peters, C. (2003). Managed Forest Gardens in West Kalimantan, Indonesia. In Potter, C. S. et al. (ed.), Perspectives on Biodiversity: Case Studies of Genetic Resource Conservation and Development. AAAS, Washington.

Padoch, C., Coffey, K., Mertz, O., Leisz, S. J., Fox, J., Wadley, R. L. (2007). The demise of swidden in Southeast Asia? Local realities and regional ambiguities. Geografisk Tidsskrift, Danish Journal of Geography 107 (1): 29-41.

Pei, S. (1993). Managing for biological diversity conservation in temple yards and holy hills - the traditional practices of the Xishuangbanna Dai community, Southwestern China. In Hamilton, L. S. (ed.), Ethics, Religion and Biodiversity. White Horse Press, Cambridge, UK, pp. 112-118.

Peluso, N., and Padoch, C. (1996). Changing resource rights in managed forests of West Kalimantan. In Padoch, C., and Peluso, N. L. (eds.), Borneo in Transition: People, Forests, Conservation, and Development, Oxford University Press, Kuala Lumpur, pp. 121-136.

Peters, C. M. (2003). Illipe Nuts (Shorea spp.) in West Kalimantan: Use, Ecology, and Management Potential of an Important Forest Resource. In Padoch, C., and Peluso, N. L. (eds.), Borneo in Transition: People, Forests, Conservation, and Development. 2nd edn., Oxford University Press, Kuala Lumpur.

Price, L. L., and Ogle, B. M. (2008). Gathered indigenous vegetables in Mainland Southeast Asia: a gender asset. In Resurreccion, B., and Elmhirst, R. (eds.), Gender and Natural Resource Management: Livelihoods, Mobility and Interventions. Earthscan, London, pp. 213-242.

Qiu, J. (2009). Where the Rubber Meets the Garden. Nature 457: 246247.

Rasul, G., and Thapa, G. B. (2003). Shifting cultivation in the mountains of South and Southeast Asia: regional patters and factors influencing change. Land Degradation and Development 14: 495-508.

Renard, R. D. (2001). Opium Reduction in Thailand 1970-2000. A Thirty Years of Journey. Silkworm Book for the United Nations International Drug Control Programme, Regional Centre for East Asia and the Pacific, Bangkok, p. 199.

Rerkasem, B. (1996). Montane Mainland Southeast Asia in Transition. Chiang Mai University, Chiang Mai.

Rerkasem, B. (2008). Diversity of Local Germplasm and Rice Farming: A Cse Study of Thailand. Biodiversity Journal 9: 49-51.

Rerkasem, K., Rerkasem, B., Kaosard, M., Roongruengsee, C., and Israngura, A. (1989). Highland development as narcotic prevention strategy. Institute of Northern Community Service, Chiang Mai University, Chiang Mai.

Rerkasem, B., Yoneyama, T., and Rerkasem, K. (1992). Spineless Mimosa (Mimosa invisa), a potential live mulch for corn, Agricultural Systems Programme, Working Paper No. 1. Chiang Mai University, Chiang Mai.

Rigg, J. (2002). Roads, Marketization and Social Exclusion in Southeast Asia. What Do Roads do to People? Bijdragen tot de Taal-, land- an Volkenkunde 158 (4): 619-636.

Roder, W., Phengchanh, S., and Maniphoe, S. (1997). Dynamics of Soil and Vegetation During Crop and Fallow Period in Slash-andBurn Fields of Northern Laos. Geoderma 76: 131-144.

Sabhasri, S. (1978). Effects of forest fallow cultivation on forest production and soil. In Kunstadter, P., Chapman, E. C., and Sabhasri, S. (eds.) Farmers in the Forest: Economic Development and Marginal Agriculture in Northern Thailand, pp. 160-184.

Salas, M. A. (2006). Pga k'nyau: Knowledge on Rotational Farming in Northern Thailand. IKAP-Network, Chiang Mai, Thailand. 
Santasombat, Y. (2003). Biodiversity: Local Knowledge and Sustainable Development. Within Design Company for the Regional Center for Social Science and Sustainable Development, Chiang Mai University, Chiang Mai, p. 247.

Schmidt-Vogt, D. (1998). Defining Degradation: The Impacts of Swidden on Forests in Northern Thailand. Mountain Research and Development 18 (2): 135-149.

Schmidt-Vogt, D. (1999). Swidden Farming and Fallow Vegetation in Northern Thailand. Geoecological Research Vol. 8. Franz Steiner Verlag, Stuttgart, Germany.

Schmidt-Vogt, D. (2001). Secondary Forests in Swidden Agriculture in the Highlands of Thailand. Journal of Tropical Forest Science 13 (4): 748-767.

Schmidt-Vogt, D. (2007). Relict emergents in swidden fallows of the Lawa in Northern Thailand: Ecology and Economic Potential. In Cairns, M. (ed.), Voices from the Forest: Integrating Indigenous Knowledge into Sustainable Upland farming. Resources for the Future, Washington, DC, pp. 37-53.

Sillitoe, P. (1995). Fallow and Fertility Under Subsistence Cultivation in the New Guinea Highlands. I. Fallow Successions. Singapore Journal of Tropical Geography 16 (1): 82-100.

Spencer, J. E. (1966). Shifting Cultivation in Southeastern Asia. University of California Press, Berkeley and Los Angeles.

Sturgeon, J. C. (2005). Border Landscapes: The Politics of Akha Land Use in China and Thailand. U. of Washington Press, Seattle.

Sutthi, C. (1989). Highland agriculture: from better to worse. In McKinnon, J., and Vienne, B. (eds.), Hill Tribe Today. White Lotus for OSTROM, Bangkok, pp. 107-142.

Sutthi, C. (1995). Swidden Crop Germplasm in the Highlands of Thailand. Tribal Research Institute, Chiang Mai.

Thongmanivong, S., Fujita, Y., and Fox, J. (2005). Resource Use Dynamics and Land-Cover Change in Ang Nhai and Phou Phanang National Forest Reserve, Lao PDR. Environmental Management 36: 382-393.

Trenbath, B. R. (1984). Decline of soil fertility and the collapse of shifting cultivation systems under intensification. In Cladwick, A. C., and Sutton, S. L. (eds.), The Tropical Rain Forests: the Leeds Symposium. Leeds Philosophical and Literary Society, London, pp. 279-292.

Trenbath, B. R., Conway, G. R., and Craig, I. (1990). Threats to sustainability in intensified agricultural systems: analysis and implications for management. In Gliessman, S. R. (ed.), Agroecology: Researching the Ecological Basis of Sustainable Agriculture. Springer, New York, pp. 337-366.

Vandermeer, J., Lawrence, D., Symstad, A., and Hobbie, S. (2002). Effect of biodiversity on ecosystem function in managed ecosystems. In Loreau, M., Naeem, S., and Inchausti, P. (eds.), Biodiversity and Ecosystem Functioning: Synthesis and Perspectives. Oxford University Press, Oxford, pp. 221-233.
Wang, Z. J., and Young, S. S. (2003). Differences in Bird Diversity Between Two Swidden Agricultural Sites in Mountainous Terrain, Xishuangbanna, Yunnan, China. Biological Conservation 110: 231-243.

Warner, K. (1991). Shifting Cultivators: Local Technical Knowledge and Natural Resource Management in the Humid Tropics. FAO, Rome.

$\mathrm{Xu}$, J. (2006). The Political, Social, and Ecological Transformation of a Landscape: The Case of Rubber in Xishuangbanna, China. Mountain Research and Development 26 (3): 254-262.

$\mathrm{Xu}$, J. (2007). Rattan and tea-based intensification of shifting cultivation by Hani farmers in southwestern China. In Cairns, M. (ed.), Voices from the Forest: Integrating Indigenous Knowledge into Sustainable Upland farming. Resources for the Future, Washington, DC, pp. 664-672.

Yimyam, N. (2006). Fallow regeneration and upland rice yield variation in a system of shifting cultivation with Pada (Macaranga denticulata (B1.) Muell. Arg.) as fallow enriching species in northern Thailand. PhD Thesis (Agronomy), Graduate School, Chiang Mai University.

Yimyam, N., Rerkasem, K., and Rerkasem, B. (2003). Fallow Enrichment with Pada (Macaranga denticulata (B1.) Muell. Arg.) Trees in Rotational Shifting Cultivation in Northern Thailand. Agroforestry Systems 57: 79-86.

Yimyam, N., Youpensuk, S., Wongmo, J., Kongpan, A., Rerkasem, B., and Rerkasem, K. (2008). Arbuscular Mycorrhizal Fungi, an Underground Resource for Sustainable Upland Agriculture. Biodiversity Journal 9: 61-63.

Yin, S. (2001). (tr.by Magnus Fiskejo) People and Forests: Yunnan Swidden Agriculture in Human-Ecological Perspective. Yunnan Education, Kunming.

Youpensuk, S., Rerkasem, B., Dell, B., and Lumyong, S. (2005). Effects of Arbuscular Mycorrhizal Fungi on a Fallow Enriching Tree (Macaranga denticulate). Fungal Diversity 18: 189-199.

Ziegler, A. D., Giambelluca, T. W., Tran, L. T., Vana, T. T., Nullet, M. A., Fox, J. M., Vien, T. D., Pinthong, J., Maxwell, J. F., and Evett, S. (2004). Hydrological Consequences of Landscape Fragmentation in Mountainous Northern Vietnam: Evidence of Accelerated Overland Flow Generation. Journal of Hydrology 287: 124-146.

Ziegler, A. D., Fox, J., and Xu, J. (2009a). The rubber juggernaut. Science 324:1024-1025.

Ziegler, A. D., Bruun, T. B., Gardiola-Claramonte, M. Giambelluca, T. W., Lawrence, D., Nguyen Thanh Lam. (2009b). Environmental Consequences of the Demise in Swidden Agriculture in SE Asia: Geomorphological processes. Human Ecology, this issue.

Zinke, P., Sabhasri, S., and Kunstadter, P. (1978). Soil fertility aspects of the Lua forest fallow system of shifting cultivation. In Kunstadter, P., Chapman, E. C., and Sabhasri, S. (eds.), Farmers in the Forest: Economic development and marginal agriculture in northern Thailand, pp. 134-159. 